\title{
Pemanfaatan Sampah Organik (Kelapa Muda, Tulang Ikan Dan Limbah Udang) di Kawasan Pantai Glagah Kulon Progo Yogyakarta
}

\author{
Yebi Yuriandala ${ }^{1, a)}$, Hijrah Purnama Putra ${ }^{1)}$, Hilda Ageng Ilmira ${ }^{1)}$, Resti Malida Putri ${ }^{1)}$ \\ ${ }^{1)}$ Teknik Lingkungan, Fakultas Teknik Sipil dan Perencanaan, Universitas Islam Indonesia \\ ${ }^{\text {a)} E m a i l ~ k o r e s p o n d e n s i: ~ y e b i . y @ u i i . a c . i d ~}$
}

\begin{abstract}
ABSTRAK
Pantai Glagah tidak hanya menyediakan destinasi alam yang indah, pengunjung juga dapat menikmati makanan hasil olahan laut dan minuman kelapa yang disajikan di warung kuliner. Aktifitas pariwisata tersebut dapat menimbulkan permasalahan sampah organik berupa sampah sisa makanan dan kelapa dari warung kuliner. Sampah organic jika tidak dikelola maka akan menimbulkan dampak negatif bagi lingkungan. Penelitian ini bertujuan melakukan pemanfaatan sampah organik terutama sampah kelapa yang dimanfaatkan menjadi briket, serta sampah tulang ikan dan udang menjadi pelet pakan ikan. Pengolahan kelapa menjadi briket menggunakan metode pirolis dengan memvariasikan suhu pirolisis dan kadar perekat. Berdasarkan hasil analisis di dapat hasil nilai kalor tertinggi terdapat pada briket dengan suhu pirolisis $350^{\circ} \mathrm{C}$ dan konsentrasi perekat $10 \%$ sebanyak 6.383,95 Kal/gram, kadar volatile dari keempat variasi briket melebihi standar yang ditetapkan oleh SNI 01-6235-2000 tentang briket arang kayu. Sedangkan pengolahan limbah tulang ikan dan udang menjadi pelet pakan ikan menggunakan perhitungan variasi formulasi dengan metode Pearson Square. Pengujian kimia menggunakan analisis proksimat dengan 3 variasi pelet. Pelet A memiliki kualitas paling baik diantara ketiga variasi, dengan jumlah kadar air 16,48\%, kadar abu 31,66\%, kadar protein 14,68\%, kadar lemak 3,63\%, dan serat kasar $18,61 \%$.
\end{abstract}

Kata kunci: briket; pelet pakan ikan; pirolisis; sampah

\begin{abstract}
Glagah Beach not only provides beautiful natural destinations, visitors can also enjoy processed seafood and coconut drinks served at culinary stalls. These tourism activities can cause organic waste problems in the form of food scraps and coconuts from culinary restaurants. Organic waste, if not managed, will have a negative impact on the environment. This study aims to utilize organic waste, especially coconut waste produced to briquettes, as well as fish and shrimp bone waste into fish feed pellets. Processing coconut into briquettes using the pyrolysis method by the pyrolysis temperature and adhesive content variations. Based on the results, the highest calorific value is found in briquettes with pyrolysis temperature of $350^{\circ} \mathrm{C}$ and $10 \%$ adhesive concentration of 6,383.95 Cal/gram, the volatile content of the four variations of briquettes exceeds the standards stipulated by SNI 01-6235-2000 on briquettes wood charcoal whereas the processing of fish and shrimp bone waste into fish feed pellets uses the calculation of formulation variations by the Pearson Square method. Chemical testing using proximate analysis with 3 variations of pellets. Pellet A has the best quality among the three variations, with $16.48 \%$ water content, $31.66 \%$ ash content, $14.68 \%$ protein content, $3.63 \%$ fat content, and $18.61 \%$ crude fiber.
\end{abstract}

Keywords: briquette; fish feed pellets; pyrolysis; solid waste.

\section{PENDAHULUAN}

Pantai Glagah adalah salah satu pantai yang terletak di Kabupaten Kulon Progo tidak hanya memiliki destinasi alam yang indah, tetapi di pantai ini pengunjung juga dapat menikmati makanan hasil olahan laut dan minuman kelapa muda yang disajikan dari puluhan warung kuliner sehingga pantai ini sering menjadi destinasi utama masyarakat yang berkunjung ke Kulon Progo. Aktivitas pariwisata serta peningkatan jumlah wisatawan maka akan menimbulkan permasalahan sampah, dimana $86 \%$ merupakan sampah organik berupa sampah kelapa muda $43 \%$ dan tulang ikan dan kulit udang 4\% serta sisa makanan lainnya 43\% yang berasal dari warung kuliner (Hikmawan, 2017).

pengelolaan sampah kelapa muda, tulang ikan, kulit udang dan sisa-sisa makanan di Pantai Glagah hanya dibuang dan ditumpuk di tempat pengumpulan sampah bercampur dengan sampah anorganik lainnya, kemudian sampah akan diangkut oleh truk pengangkut sampah seminggu sekali. Namun, kondisi bak sampah yang terlalu kecil membuat sampah sering melebihi kapasitas bak dan menimbulkan bau. Hal ini jika tidak ditangani dengan baik akan mengurangi nilai estetika dan menganggu kenyamanan wisatawan yang berkunjung.

Limbah kelapa muda tersebut dapat dimanfaatkan sebagai sumber energi alternatif salah satunya adalah pemanfaatan menjadi briket bioarang. Mulyadi, dkk (2013) menyatakan bahwa beberapa keuntungan dari pemanfaatan biomassa 
sebagai energi alternatif antara lain persediaan bahan baku yang melimpah, harga yang murah serta teknologi yang digunakan mudah.

Sampah tulang ikan dan Limbah udang mempunyai kandungan zat-zat makanan yang cukup tinggi terutama kandungan proteinnya, sehingga limbah tersebut dapat dimanfaatkan sebagai salah satu bahan penyusun ransum ternak (Palupi, 2007), Tulang ikan banyak mengandung kalsium dalam bentuk kalsium fosfat sebanyak $14 \%$ dari total susunan tulang (Subangsihe,1996) dalam Nabil, 2005). Sedangkan limbah udang yang berupa kulit, kepala, dan ekor mengandung senyawa kimia berupa kitin, kitosan, protein, kalsium karbamat, lemak, air, abu, dan lain-lain (Fachry, 2012).

Penelitian ini bertujuan melakukan pemanfaatan sampah organik terutama sampah kelapa muda yang akan dimanfaatkan menjadi briket, serta sampah tulang ikan dan udang menjadi pelet pakan ikan. Pengolahan kelapa menjadi briket menggunakan metode pirolis dengan memvariasikan suhu pirolisis dan kadar perekat. Untuk pengolahan limbah tulang ikan dan udang menjadi pelet pakan ikan menggunakan perhitungan variasi formulasi dengan metode Pearson Square. Pengujian kimia menggunakan analisis proksimat dengan 3 variasi pelet. Hasil analisis kemudian disesuaikan dengan standar baku mutu pakan ikan yaitu SNI-01-4087-2006 (syarat mutu pakan ikan lele), SNI-01-7242-2006 (syarat mutu pakan ikan nila), dan SNI-7473:2009 (syarat mutu pakan ikan gurami).

\section{METODE}

\subsection{Lokasi Penelitian}

Lokasi pengambilan sampel adalah warung kuliner di sekitar laguna dan pasar Pantai Glagah, sedangkan proses pembuatan briket dan pelet dilaksanakan di Laboratorium Perpindahan Panas dan Massa Pusat Antar Universitas (PAU) Universitas Gadjah Mada Yogyakarta.

\subsection{Alat dan Bahan}

Peralatan yang digunakan dalam pembuatan briket antara lain reaktor pirolisis, ayakan ukuran 50 mesh, alat pengepres briket, penghancur arang, timbangan analitik, timbangan elektronik, kompor, panci, sendok, ember kecil, sarung tangan, kertas label, dan parang. Bahan yang digunakan dalam penelitian ini antara lain limbah kelapa muda, tepung tapioka, dan air. Sedangkan dalam pembuatan pelet ikan, peralatan yang digunakan adalah Blender, Panci, Ayakan, Timbangan, Sendok, , Cetakan pelet, Plastik, Kompor, dan Tampah. Sedangkan bahan-bahan yang digunakan yaitu limbah tulang ikan, limbah kulit udang, bekatul, tepung ikan Protein $40 \%$, tepung kanji dan air.

\subsection{Prosedur kerja}

\section{Briket Limbah Kelapa Muda}

Limbah kelapa muda yang telah dikumpulkan dari penjual es kelapa muda kemudian dicacah ukuran $\pm 5 \mathrm{~cm}$ kemudian dikeringkan dibawah sinar matahari selama kurang lebih 5 hari untuk mengurangi kadar air. Setelah kering kemudian dilakukan proses pirolisis dengan variasi suhu $300^{\circ} \mathrm{C}$ (A) dan $350^{\circ} \mathrm{C}$ (B) selama kurang lebih 6 jam. Skema alat pirolisis dapat dilihat pada Gambar 1. Arang yang didapat dari proses pirolisis kemudian dihaluskan dan diayak menggunakan ayakan 50 mesh dan selanjutnya dicampur dengan perekat. Perekat yang digunakan yaitu tepung tapioka yang dicampur dengan air dengan variasi penambahan tepung sebanyak $10 \%$ dan $15 \%$ dari berat serbuk arang. Adonan diaduk hingga homogen kemudian dicetak dengan tekanan sebesar $50 \mathrm{~kg} / \mathrm{cm}^{2}$. Briket yang sudah dicetak dikeringkan dalam oven dengan suhu $100^{\circ} \mathrm{C}$ selama 4 jam untuk kemudian dilakukan uji kualitas briket dengan parameter kadar air, kadar abu dan nilai kalor.

\section{Pelet Pakan Ikan}

Proses pembuatan pelet pakan ikan diawali dengan persiapan bahan baku masing-masing sebanyak 500 gram.. Bahan baku yang digunakan adalah limbah tulang ikan, bekatul, limbah udang. Pembuatan pelet dimulai dengan mengumpulkan bahan baku limbah tulang ikan dan limbah udang dari warung-warung kuliner di Pantai Glagah. Seluruh bahan baku limbah ditimbang lalu dibersihkan. Setelah itu dikukus (60 menit) dan dijemur (7 hari) untuk mengurangi kadar airnya. Selanjutnya bahan baku harus dihaluskan hingga berbentuk tepung. Tepung kemudian dianalisis proksimat untuk mengetahui kandungan gizinya, yaitu kadar air, abu, lemak, protein, dan serat kasar. Berdasarkan hasil proksimat, kemudian dibuat tepung campuran dengan penambahan bahan baku berupa tepung ikan untuk membuat bahan protein suplemen, sebelum menyusun formulasi pakan. Komposisi tepung campuran merupakan gabungan dari tepung ikan dan tepung udang dengan $35 \%$ kandungan protein.

Penyusunan formulasi pakan menggunakan metode Pearson Square (Gambar 2), yaitu suatu metode sistem pencampuran pakan dengan memakai metode matematika secara sederhana. Sistem ini mencoba mengurangkan dan menambahkan komposisi zat-zat makanan yang dicampurkan. Perhitungan dibuat berdasarkan nilai kandungan protein target yang dibutuhkan ikan yang mengonsumsi yaitu ikan lele, nila, dan gurami. 


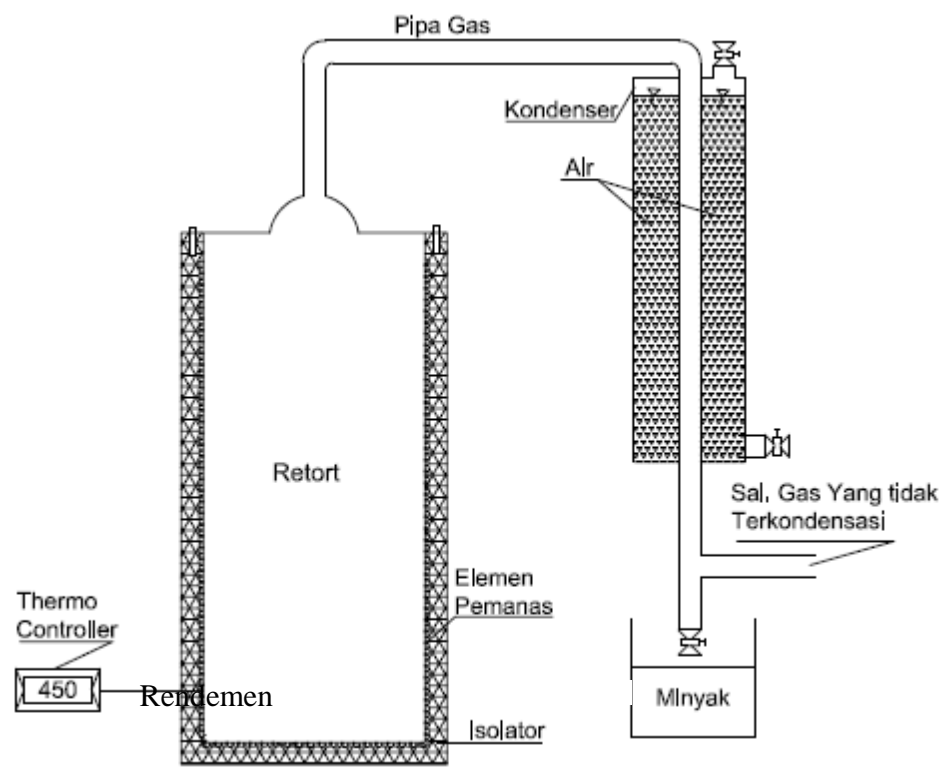

Gambar 1. Alat Pirolisis
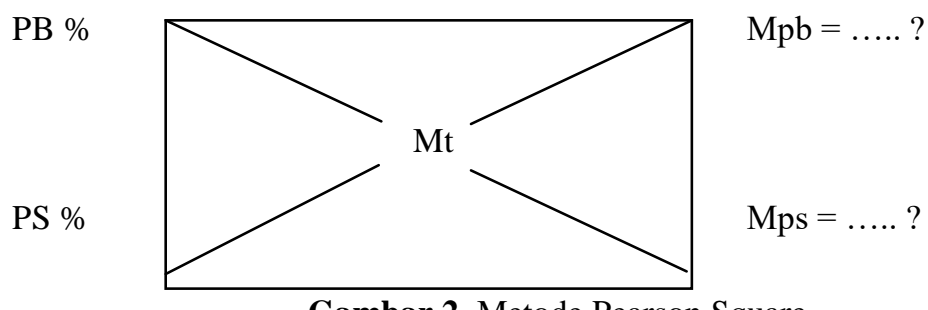

Gambar 2. Metode Pearson Square

Dimana :

$$
\begin{aligned}
M p b & =\frac{P S-P}{(P S-T)+(T-P B)} \times 100 \% \\
M p s & =\frac{T-P S}{(P S-T)+(T-P B)} \times 100 \%
\end{aligned}
$$

Keterangan:

PB : persentase protein basal

PS : persentase protein suplemen

$\mathrm{Mpb}$ : berat bahan baku protein basal yang dibutuhkan

Mps : berat bahan baku protein suplemen yang dibutuhkan

$\mathrm{P} \quad$ : persentase target kandungan protein

Mt : berat target

Pada penelitian ini mengacu pada protein target ikan yang sesuai dengan syarat mutu pakan ikan yakni, ikan lele (SNI01-4087-2006), ikan nila (SNI-01-7242-2006), dan ikan gurami (SNI-7473:2009). Berdasarkan perhitungan, diperoleh variasi campuran bahan pelet pakan ikan terdapat pada Tabel 1.

Tabel 1. Variasi Campuran Bahan Pakan

\begin{tabular}{cccccc}
\hline Variasi Pakan & $\begin{array}{c}\text { Bobot Tepung } \\
\text { Tulang Ikan }(\mathbf{g r})\end{array}$ & $\begin{array}{c}\text { Bobot Bekatul } \\
(\mathbf{g r})\end{array}$ & $\begin{array}{c}\text { Bobot Tepung } \\
\text { Campuran }(\mathbf{g r})\end{array}$ & $\begin{array}{c}\text { Bobot Tepung } \\
\text { Kanji (gr) }\end{array}$ & Air (\%) \\
\hline Pelet A & 17.81 & 17.81 & 64.38 & 5 & 30 \\
\hline
\end{tabular}




\begin{tabular}{cccccc}
\hline Pelet B & 12.47 & 12.47 & 75.06 & 5 & 30 \\
Pelet C & 5.34 & 5.34 & 89.32 & 5 & 30 \\
\hline
\end{tabular}

Sumber : Analisis 2017

Semua bahan yang terdiri atas tepung tulang ikan, bekatul, tepung campuran, dan kanji, dicampur dengan komposisi sesuai formulasi untuk setiap variasi pelet. Kemudian sedikit demi sedikit bahan dicampurkan ke dalam perekat dimulai dari bahan yang jumlahnya paling sedikit hingga ke bahan yang jumlahnya banyak, agar semua bahan dapat tercampur rata dan membentuk adonan pasta. Setelah itu barulah adonan pelet dicetak dan dijemur. Pelet yang sudah dicetak kemudian analisis kandungan kimianya untuk mengetahui kualitas dari masing-masing variasi, yaitu kadar air, abu, lemak, protein, dan serat kasar.

\section{HASIL DAN PEMBAHASAN}

\subsection{Uji Proksimat Bahan Baku}

\section{1) Briket Limbah Kelapa Muda}

Limbah kelapa muda memiliki kadar air tertinggi dan kadar abu terendah. Dari perbandingan beberapa bahan baku, kualitas limbah kelapa muda lebih baik dari beberapa bahan seperti tandan kosong kelapa sawit dan jerami (Tabel 2), hal ini karena limbah kelapa muda memiliki nilai kalor yang lebih tinggi.

Tabel 2. Perbandingan Hasil Analisa Proksimat

\begin{tabular}{|c|c|c|c|c|c|}
\hline \multirow[t]{2}{*}{ Parameter } & \multicolumn{5}{|c|}{ Bahan Baku } \\
\hline & $\begin{array}{l}\text { Tandan Kosong } \\
\text { Kelapa Sawit }^{(a)}\end{array}$ & $\begin{array}{c}\text { Limbah } \\
\mathrm{Bambu}^{(\mathrm{b})}\end{array}$ & $\begin{array}{l}\text { Tempurung } \\
\text { Kelapa }^{(\mathrm{c})}\end{array}$ & Jerami $^{(c)}$ & $\begin{array}{c}\text { Limbah Kelapa } \\
\text { Muda }^{(d)}\end{array}$ \\
\hline Kadar Air (\%) & 12,59 & 12,06 & 10,55 & 18,98 & 25,95 \\
\hline Kadar Volatile (\%) & 65,38 & 61,97 & 10,85 & 12,29 & 54,07 \\
\hline Kadar Abu (\%) & 4,13 & 2,70 & 3,22 & 61,96 & 1,94 \\
\hline Kadar Karbon Terikat (\%) & 17,90 & 23,27 & 78,32 & 15,61 & 18,04 \\
\hline Nilai Kalori (Kalori/gram) & 3794,86 & 4592,55 & 7283,50 & 1525,50 & 3879,12 \\
\hline
\end{tabular}

Sumber: (a) Ristianingsih, dkk (2015), (b) Putra, dkk (2013), (c) Yerizam, dkk (2013), (d) Hasil Pengujian

\section{2) Pelet Pakan Ikan}

Analisis proksimat dilakukan terhadap bahan baku tepung tulang ikan, tepung limbah udang, dan bekatul unutk mengetahui kandungan gizi pada bahan baku penyusun pakan. Hasil proksimat juga dilakukan sebelum melakukan penyusunan formulasi pakan untuk mengetahui kandungan protein bahan baku. Analisis proksimat yang dilakukan antara lain kadar air, abu, lemak, serat kasar, dan protein yang dapat dilihat pada Tabel 3.

Tabel 3. Hasil Analisis Proksimat Bahan Baku

\begin{tabular}{lccc}
\hline \multicolumn{1}{c}{ Macam Analisis } & \multicolumn{3}{c}{ Hasil Uji } \\
\cline { 2 - 4 } & Tepung Tulang Ikan & Tepung Limbah Udang & Bekatul \\
Air (\%) & 9.12 & 13.34 & 12.53 \\
Abu (\%) & 43.51 & 28.44 & 9.36 \\
Protein (\%) & 9.89 & 13.22 & 3.97 \\
Lemak (\%) & 16.16 & 3.59 & 7.09 \\
Serat Kasar (\%) & 12.67 & 20.81 & 14.32 \\
\hline
\end{tabular}

Sumber: Data Primer, 2017

\subsection{Hasil Rendemen Limbah Kelapa Muda}

Rendemen arang yang dihasilkan setelah proses pirolisis terdapat pada tabel 4 . Rendemen arang limbah kelapa muda setelah dilakukan pirolisis pada suhu $300^{\circ} \mathrm{C}$ yaitu sebesar $32.75 \%$ dan rendemen arang limbah kelapa muda setelah dilakukan pirolisis pada suhu $350^{\circ} \mathrm{C}$ yaitu sebesar $28.21 \%$. Menurut Sudrajat (1997) dalam Noviyarsi, dkk (2015) di Indonesia, rendemen arang kayu yang baik berada pada kisaran $21.1 \%-40.8 \%$. Hasil rendemen arang limbah kelapa 
muda berada dalam kisaran rendemen arang yang baik, sehingga limbah bambu dapat dimanfaatkan menjadi briket. Hasil pirolisis limbah kelapa muda dapat dilihat pada Tabel 4.

Tabel 4. Hasil Pirolisis Limbah Kelapa Muda

\begin{tabular}{llccc}
\hline \multicolumn{1}{c}{ Bahan Baku } & \multicolumn{1}{c}{$\begin{array}{c}\text { Berat Sebelum } \\
\text { Pirolisis } \\
\text { (gram) }\end{array}$} & $\begin{array}{c}\text { Berat Setelah } \\
\text { Pirolisis } \\
\text { (gram) }\end{array}$ & $\begin{array}{c}\text { Rendemen } \\
(\%)\end{array}$ \\
\hline $\begin{array}{l}\text { Limbah Kelapa } \\
\text { Pirolisis 300 }\end{array}$ & $\begin{array}{l}\text { C } \\
\text { Limbah } \\
\text { Pirolisis 350 }\end{array}{ }^{\circ} \mathrm{C}$
\end{tabular}

Sumber : analisis data 2017

\subsection{Analisis Kualitas Briket}

Pengujian kualitas briket limbah kelapa muda meliputi uji kadar air, kadar volatile, kadar abu, kadar karbon terikat, serta nilai kalor briket.

\section{1) Analisis Kadar Air}

Kadar air mempengaruhi kualitas dari briket, semakin sedikit kadar air yang terkandung dalam briket, maka kualitas briket semakin baik. Kadar air besar menyebabkan briket susah untuk dinyalakan, oleh karena itu kadar air dalam briket harus serendah mungkin. Hasil kadar air briket limbah kelapa muda terdapat pada Gambar 3.

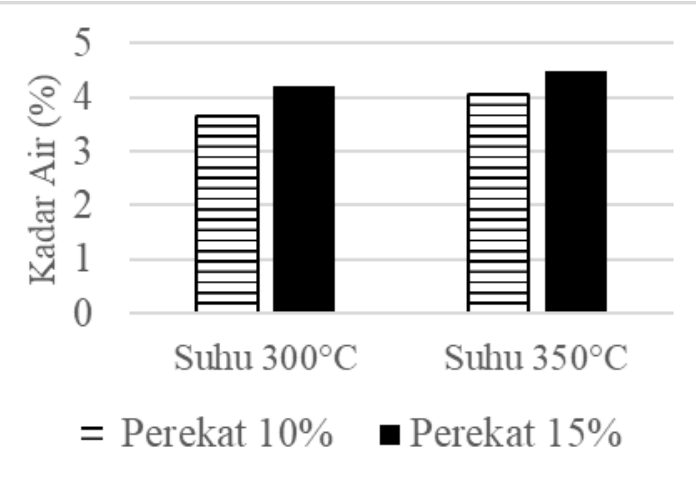

Gambar 3. Pengaruh Variasi Suhu dan Perekat Terhadap Kadar Air Sumber : analisis data, 2017

Dari hasil analisis kualitas briket didapat hasil kadar air tertinggi terdapat pada briket dengan konsentrasi perekat $15 \%$ pada suhu $350^{\circ} \mathrm{C}$. Sedangkan nilai kadar air terendah terdapat pada briket dengan konsentrasi perekat $10 \%$ pada suhu $300^{\circ} \mathrm{C}$. Meningkatnya kadar air seiring dengan bertambahnya kadar perekat dikarenakan adanya kandungan air yang terdapat dalam perekat. Semakin tinggi suhu kadar air bertambah tinggi. Hal ini karena lamanya proses pendinginan dari arang limbah kelapa muda yang dipirolisis pada suhu $350^{\circ} \mathrm{C}$ serta tingginya kandungan karbon dalam arang sehingga pada saat penyimpanan akan menyerap air dari lingkungan sekitar. Dibandingkan dengan SNI 01-6235-2000 semua variasi telah memenuhi standar yaitu dibawah 8\%. Ristianingsih (2015) dalam penelitiannya mengatakan bahwa kadar air yang terkandung dalam perekat akan mempengaruhi kadar air briket ketika dicampur dengan arang TKKS. Menurut Maryono, dkk (2013) dalam penelitiannya bahwa semakin tinggi kadar perekat yang ditambahkan, akan membuat air yang terperangkap dalam arang semakin banyak.

\section{2) Analisis Kadar Volatile}

Menurut Pane (2015), kadar volatile atau zat terbang merupakan zat yang dapat menguap sebagai hasil dekomposisi dari zat - zat penyusun arang di dalam bahan yang disebabkan oleh proses pemanasan selain air. Dari hasil analisis kualitas briket didapat hasil kadar volatile tertinggi terdapat pada briket dengan konsentrasi perekat $15 \%$ pada suhu $300^{\circ} \mathrm{C}$, sedangkan nilai kadar volatile terendah terdapat pada briket dengan konsentrasi perekat $10 \%$ pada suhu $350^{\circ} \mathrm{C}$. Gambar 4 menunjukkan kadar volatile meningkat setelah dilakukan penambahan perekat. Peningkatan kadar volatile terjadi karena kandungan zat menguap yang terdapat dalam perekat dan bahan baku. Untuk variasi suhu, semakin bertambah suhu kadar volatile yang terkandung dalam briket semakin kecil. Hal ini karena semakin tinggi suhu pirolisis akan 
semakin banyak zat mudah menguap yang terkandung dalam briket yang terbuang. Dibandingkan dengan SNI 01-62352000, semua variasi belum memenuhi standar karena masih lebih dari $15 \%$.

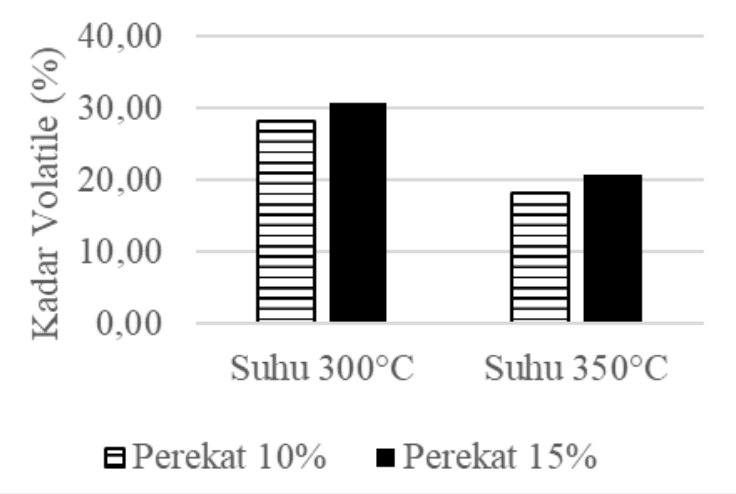

Gambar 4. Pengaruh Variasi Suhu dan Perekat terhadap Kadar Volatile

Sumber: analisis data, 2017

Kadar volatile di dalam briket akan bertambah seiring dengan bertambahnya kadar kanji dalam briket (Maryono, dkk, 2013). Hal ini karena zat - zat volatile yang terkandung dalam arang dan kanji pada saat briket dipanaskan ikut menguap. Kadar volatile juga dipengaruhi oleh suhu serta lamanya proses pirolisis. Eijayanti (2009) dalam Pane, dkk (2015) dalam penelitiannya menyebutkan bahwa semakin tinggi suhu yang digunakan untuk pirolisis bahan baku briket serta semakin lama waktu pirolisis maka akan menyebabkan banyak zat volatile yang menguap.

\section{3) Analisis Kadar Abu}

Kadar abu merupakan jumlah sisa dari proses pembakaran yang tidak memiliki unsur karbon. Kandungan utama dalam abu adalah silika. Semakin banyak kadar abu yang terdapat dalam briket, maka kualitas briket tersebut semakin rendah. Dari hasil analisis kualitas briket didapat hasil kadar abu tertinggi terdapat pada briket dengan konsentrasi perekat $10 \%$ pada suhu $350^{\circ} \mathrm{C}$, sedangkan nilai kadar abu terendah terdapat pada briket dengan konsentrasi perekat $15 \%$ pada suhu $300^{\circ} \mathrm{C}$. Dalam Gambar 5 terlihat bahwa kadar abu menurun setelah kadar perekat ditambahkan. Hal ini disebabkan karena semakin sedikit kelapa muda yang terkandung dalam briket. Kadar abu briket meningkat seiring bertambahnya suhu pirolisis. Hal ini karena semakin tinggi suhu semakin banyak zat dalam bahan baku yang terbakar dan menjadi abu. Dibandingkan dengan SNI 01-6235-2000 briket dengan konsentrasi perekat $10 \%$ dan $15 \%$ pada suhu $300^{\circ} \mathrm{C}$ yang memenuhi standar yaitu dibawah $8 \%$.

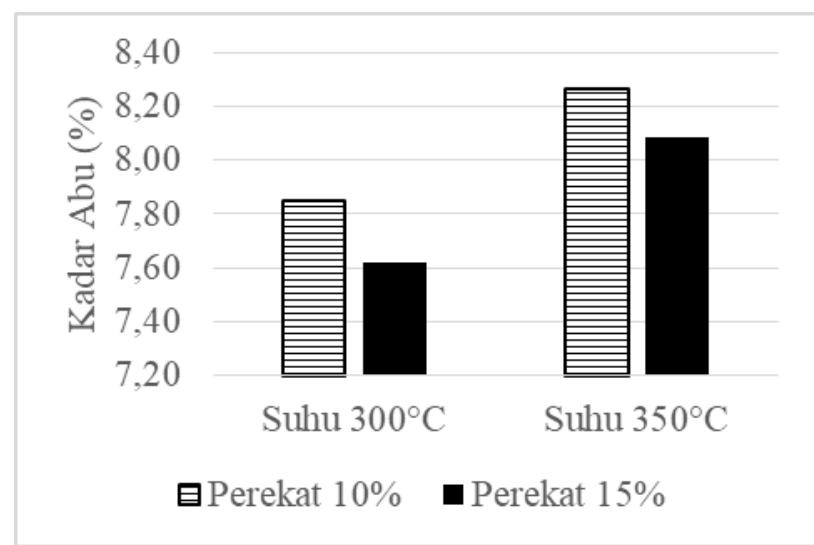

Gambar 5. Pengaruh Variasi Suhu dan Perekat terhadap Kadar Abu Sumber : Data Primer, 2017

Suryani, dkk (2012) mengatakan bahwa kadar abu dipengaruhi oleh suhu pirolisis. Semakin tinggi suhu maka semakin banyak bahan yang terbakar dan menjadi abu. Menurut Maryono (2013) tingginya kadar abu dapat dipengaruhi oleh kandungan bahan organik yang terdapat dalam perekat dan bahan baku yang tinggi. Meningkatnya kadar abu juga disebabkan oleh pengotor dari lingkungan yang bercampur pada saat proses pembuatan briket. 


\section{4) Analisis Kadar Karbon Terikat}

Karbon terikat merupakan jumlah fraksi karbon yang terikat di dalam arang. Karbon terikat dipengaruhi oleh kadar volatile. Dari hasil analisis kualitas briket didapat hasil kadar karbon terikat tertinggi terdapat pada briket dengan konsentrasi perekat $10 \%$ pada suhu $350^{\circ} \mathrm{C}$. Sedangkan nilai kadar karbon terikat terendah terdapat pada briket dengan konsentrasi perekat $15 \%$ pada suhu $300^{\circ} \mathrm{C}$. Gambar 6 menunjukkan kadar karbon terikat briket limbah kelapa muda. Semakin tinggi suhu, jumlah kadar karbon terikat semakin besar. Hal ini karena pada suhu tinggi proses pengarangan semakin cepat. Kadar karbon terikat briket limbah kelapa muda masih dibawah $77 \%$ dan belum memenuhi standar.

Menurut Putra, dkk (2013) dengan menambahkan perekat kedalam briket, maka akan mempengaruhi kadar karbon terikat karena menambahkan bahan yang tidak dipirolisis. Menurut Putro, dkk (2015) semakin tinggi temperatur karbonisasi, maka akan mempercepat proses penguraian bahan menjadi arang sehingga kadar karbon terikatnya semakin besar.

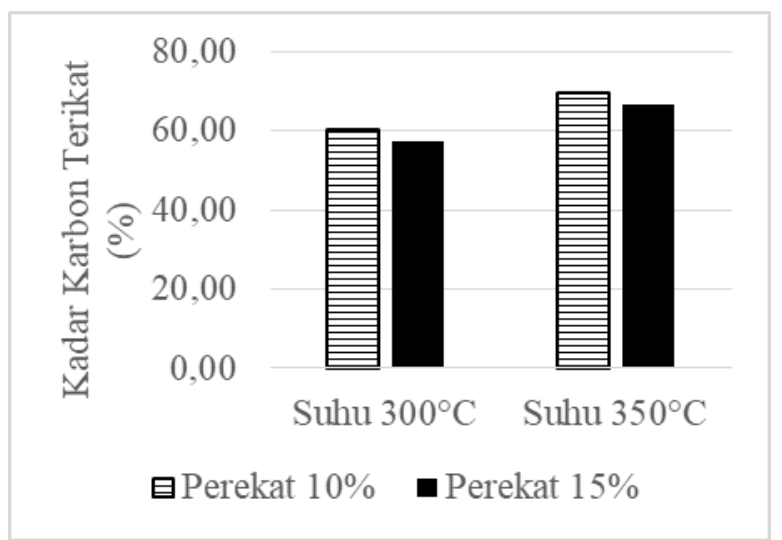

Gambar 6. Pengaruh Variasi Suhu dan Perekat terhadap Kadar Kadar Karbon Terikat

\section{5) Analisis Nilai Kalor}

Sumber : Data Primer, 2017

Nilai kalor merupakan parameter terpenting dalam penentuan karakteristik briket. Semakin tinggi nilai kalor yang dihasilkan, semakin bagus kualitas dari briket tersebut. Berdasarkan hasil analisis kualitas briket didapat hasil nilai kalor terbesar terdapat pada briket dengan konsentrasi perekat $10 \%$ pada suhu $350^{\circ} \mathrm{C}$. Sedangkan nilai kalor terendah terdapat pada briket dengan konsentrasi perekat $15 \%$ pada suhu $300^{\circ} \mathrm{C}$. Gambar 7 menunjukkan nilai kalor briket hasil pirolisis limbah kelapa muda. Nilai kalor dipengaruhi oleh kadar karbon terikat, apabila kadar karbon terikat tinggi, maka nilai kalor juga tinggi. Nilai kalor juga dipengaruhi oleh kadar air, dimana kadar air yang tinggi akan menurunkan nilai kalor. Menurut Ristianingsih, dkk (2015) kadar karbon terikat dapat mempengaruhi nilai kalor suatu briket karena pada saat pembakaran membutuhkan karbon untuk menghasilkan kalor. Dibandingkan dengan SNI 01-6235-2000 semua variasi sudah memenuhi standar karena memiliki nilai kalor lebih dari $5000 \mathrm{kal} / \mathrm{gram}$.

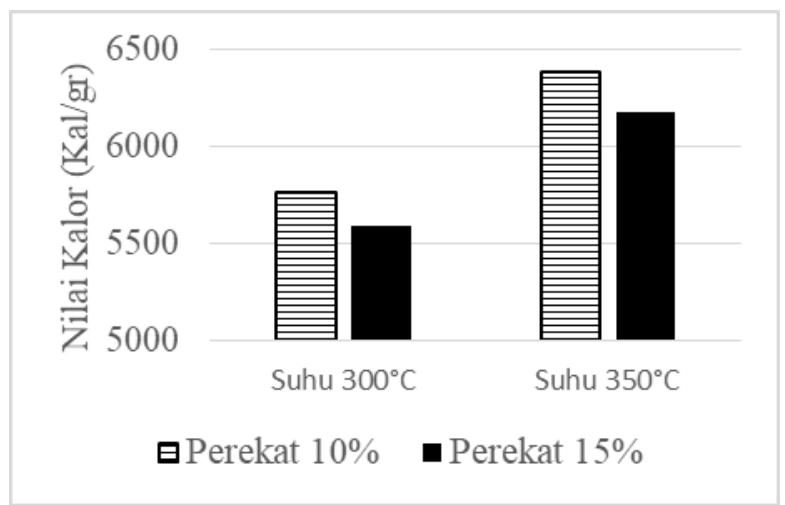

Gambar 7. Pengaruh Variasi Suhu dan Perekat terhadap Nilai Kalor Sumber : Data Primer, 2017

\subsection{Hasil uji Kualitas Pelet Ikan}

Analisis kualitas pelet ikan yang dilakukan adalah analisis kandungan air, serat kasar, kadar abu, lemak, dan protein. Karakteristik pelet yang dihasilkan mengacu pada syarat mutu pakan ikan Lele Dumbo SNI-01-4087-2006, pakan ikan Nila SNI-01-7242-2006, dan pakan ikan Gurami SNI-7473:2009 yang dapat dilihat pada Tabel 5. 
Tabel 5. Hasil Analisis Kualitas Pelet Pakan Ikan

\begin{tabular}{|c|c|c|c|c|c|c|}
\hline \multirow{2}{*}{$\begin{array}{c}\text { Variasi Sampel } \\
\text { Parameter }\end{array}$} & \multirow[t]{2}{*}{ Pelet A } & \multirow[t]{2}{*}{ Pelet B } & \multirow[t]{2}{*}{ Pelet C } & \multicolumn{3}{|c|}{ Syarat Mutu Pakan } \\
\hline & & & & Ikan Nila & $\begin{array}{c}\text { Lele } \\
\text { Dumbo }\end{array}$ & Gurami \\
\hline Kadar Air (\%) & 16,48 & 18,65 & 17,59 & 12 & 12 & 12 \\
\hline $\begin{array}{c}\text { Kadar Abu } \\
(\%)\end{array}$ & 31,66 & 31,74 & 32,66 & $13-15$ & 13 & $12-13$ \\
\hline $\begin{array}{c}\text { Kadar Protein } \\
(\%)\end{array}$ & 14,68 & 14,15 & 13,79 & $25-30$ & $25-30$ & $28-38$ \\
\hline Lemak (\%) & 3,63 & 3,05 & 2,47 & 5 & 5 & $5-7$ \\
\hline $\begin{array}{c}\text { Serat Kasar } \\
(\%)\end{array}$ & 18,61 & 22,24 & 24,45 & $6-8$ & $6-8$ & $5-8$ \\
\hline
\end{tabular}

Sumber : Analisis Data, 2017

\section{1) Kadar air}

Hasil analisa kadar air pada pelet menunjukan nilai yang belum memenuhi standar $(<12 \%)$. Kadar air tertinggi terdapat pada Pelet B yaitu $18,65 \%$, sedangkan kadar air terendah terdapat pada Pelet A yaitu 16,48\%. Adanya perbedaan kadar air karena dipengaruhi oleh kandungan air pada bahan baku yang tercampur dengan air yang berlebih. Menurut Rasyaf (1992) ada beberapa faktor yang mempengaruhi kadar air dalam suatu pakan yaitu cara penyimpanan, iklim tempat penyimpanan kemasan, dan jenis bahan baku. Tinggi rendahnya kandungan air pada bahan juga sangat dipengaruhi oleh perlakuan selama pengeringan atau penjemuran. Tingkat kekeringan pakan sangat menentukan daya tahan pakan, karena apabila pakan mengandung banyak air maka akan menjadi lembab dan apabila pakan disimpan terlalu lama akan ditumbuhi jamur. Dengan demikian, kualitas dari pakan akan menurun, bahkan dapat berbahaya bagi ikan.

\section{2) Kadar abu}

Hasil analisa kadar abu pada pelet menunjukan nilai yang tidak sesuai dengan standar $(<15 \%)$. Kandungan abu tertinggi terdapat pada pelet $\mathrm{C}$ yaitu $32,66 \%$, sedangkan kandungan abu terendah terdapat pada Pelet A sebesar 31,66\%. Kadar abu pada pakan merupakan indikator besarnya kandungan mineral dalam pakan tersebut. Hal ini menujukkan kandungan mineral tertinggi terdapat pada perlakuan Pelet C. Dari semua perlakuan, kadar abu yang dihasilkan belum memenuhi standar yang ditentukan. Kandungan abu yang tinggi pada pakan dipengaruhi oleh proses pengukusan. Pakan ikan yang terbuat dari bahan tepung mudah mengalami over cooking sehingga berakibat pada tingginya nilai kandungan abu yang terdapat pada pakan ikan (Irfak, 2013). Sehingga pada saat pengukusan sebaiknya tidak terlalu lama agar kadar abu nya tidak terlalu tinggi.

\section{3) Kadar protein}

Kandungan protein lebih tinggi terdapat pada Pelet A dibandingkan dengan pelet lain yaitu 14,68\%, sedangkan protein terendah terdapat pada Pelet C. Pakan ikan yang baik menurut standar mengandung protein berkisar $25-38 \%$, sehingga dari ketiga variasi perlakuan, kandungan protein yang dihasilkan belum memenuhi standar yang ditentukan. Menurut Irfak (2013) Penurunan kandungan protein dapat disebabkan dari proses pemasakan (pengukusan) bahan baku penyusun (tepung). Pengukusan dengan suhu tinggi akan menyebabkan protein mudah rusak.

\section{4) Kadar lemak}

Hasil analisis kandungan lemak menunjukkan nilai yang belum sesuai dengan standar yang ditentukan $(>5 \%)$. Ketiga perlakuan menghasilkan nilai kandungan lemak yang sangat rendah. Hal ini disebabkan karena kandungan lemak pada bahan penyusun pakan yang digunakan rendah sehingga ketika diproses menjadi pelet menghasilkan kandungan lemak yang rendah juga. Kandungan lemak terendah terdapat pada Pelet $\mathrm{C}$ yaitu 2,47\%, sedangkan kandungan lemak tertinggi terdapat pada Pelet A 3,63\%. Pada pakan buatan, lemak berpengaruh terhadap rasa dan tekstur pakan yang dibuat. Kandungan lemak memberikan aroma ikan pada pakan.

\section{5) Kadar serat kasar}

Hasil analisis kandungan serat kasar menunjukkan nilai yang belum sesuai dengan standar pakan ikan $(<8 \%)$. Serat kasar yang terkandung dalam pelet menunjukkan hasil yang lebih tinggi daripada standar yang ditentukan. Kandungan serat kasar yang paling tinggi terdapat pada Pelet C $(24,45 \%)$, dan yang paling rendah pada perlakuan Pelet A $(18,61 \%)$. Serat kasar yang tinggi akan meningkatkan kandungan lignin yang tinggi juga sehingga dapat menurunkan kecernaan (Daniwati, 2015). Semakin tinggi kandungan serat kasar dalam ransum, akan menurunkan kandungan dan koefisien energi, sebaliknya kebutuhan energi untuk mencerna serat meningkat. 
Faktor-faktor yang mempengaruhi perubahan hasil nilai kandungan kimia pada pelet yaitu cara penyimpanan, suhu tempat penyimpanan kemasan, jenis bahan dan lama waktu pengujian. Pelet yang diuji sebaiknya disimpan pada tempat yang kering/tidak lembab (kelembaban tak lebih dari $70 \%$ ), temperatur di kisaran $30^{\circ} \mathrm{C}-34^{\circ} \mathrm{C}$, berventilasi, terhindar sinar matahari langsung serta terhindar dari hujan dan bocor. Selain itu pastikan pelet pakan ikan benar-benar kering dan tidak disimpan terlalu lama. Tingkat kekeringan pakan sangat menentukan daya tahan pakan, karena apabila pakan mengandung banyak air maka akan menjadi lembab. Dalam kondisi ini apabila pakan disimpan terlalu lama akan ditumbuhi jamur. Dengan demikian, kualitas dari pakan akan menurun. Pada saat ingin melakukan pengujian terhadap sampel sebaiknya tidak terlalu lama, agar tidak terjadi perubahan kandungan yang sangat signifikan pada sampel. Selain itu, faktor lain yang sangat menentukan kualitas pelet adalah perlakuan selama proses pembuatan pelet. Karena seluruh proses pembuatan dilakukan secara alami dan manual, sehingga hasilnya dapat bersifat fluktuatif.

\section{KESIMPULAN}

1. Variasi optimum yang menunjukkan kualitas briket terbaik terdapat pada briket dengan suhu pirolisis $350^{\circ} \mathrm{C}$ dan kadar perekat $10 \%$ karena memiliki nilai kalor tertinggi yaitu sebesar 6383,95 kal/gr. Dari keseluruhan variasi briket, hanya pada parameter kadar air dan nilai kalor yang semuanya sudah memenuhi SNI 01-6235-2000 tentang briket arang kayu, sedangkan untuk parameter kadar volatile dan kadar karbon terikat semua variasi briket belum memenuhi standar.

2. Limbah tulang ikan dan limbah udang belum dapat dimanfaatkan sebagai penambah nutrisi pada pembuatan pelet pakan ikan. Pelet pakan ikan yang dibuat belum cukup untuk memenuhi nutrisi protein yang dibutuhkan sesuai syarat mutu. Pelet pakan ini termasuk kedalam pakan berprotein rendah. Diperlukan penambahan bahan baku lainnya yang memiliki nilai kandungan gizi protein yang lebih tinggi. Kualitas pakan yang memiliki kandungan nutrisi mendekati SNI terdapat pada variasi formulasi Pelet A dengan kadar air sebesar 16,48\%, kadar abu sebesar 31,66\%, kadar protein sebesar 14,68\%, kadar lemak sebesar 3,63\% dan kadar serat kasar sebesar 18,61\%. Kandungan protein pakan dapat ditingkatkan dengan menambahkan porsi tepung udang, tepung tulang ikan, tepung ikan, dan bahan lain yang mengandung protein tinggi.

\section{DAFTAR PUSTAKA}

Daniwati. (2015). Kandungan Protein Kasar, Serat Kasar, dan Lemak Kasar Pakan Berbasis Tongkol Jagung yang Dicampur dengan Berbagai Jenis Tepung Daun Legum. Fakultas Peternakan. Universitas Mataram.

Fachry, A. R., dan Adhestya S. (2012). Pemanfaatan Limbah Kulit Udang dan Limbah Kulit Ari Singkong Sebagai Bahan Baku Pembuatan Plastik Biodegradable. Jurnal Teknik Kimia, 18(3).

Hikmawan, M. D. (2017). Perencanaan Pengelolaan Sampah dikawasan Pantai Glagah Kabupaten Kulonprogo. Jurusan Teknik Lingkungan. Universitas Islam Indonesia.

Irfak, K. (2013). Desain Optimal Pengolahan Sludge Padat Biogas Sebagai Bahan Baku Pakan Ikan Lele di Magetan Jawa Timur. Skripsi. Fakultas Pertanian Universitas Brawijaya. Malang.

Khairuman. (2003). Pembenihan dan pembesaran Gurami secara Intensif. Agromedia Pustaka. Jakarta.

Maryono., Sudding., \& Rahmawati. (2013). Pembuatan dan Analisis Mutu Briket Arang Tempurung Kelapa Ditinjau dari Kadar Kanji. Jurnal Chemical,14(1), Hal 74-83.

Mulyadi, A.F. Dewi, I.A Doeranto, P. (2013). Pemanfaatan Kulit Buah Nipah Untuk Pembuatan Briket Bioarang Sebagai Sumber Energi Alternatif. Jurnal Teknologi Pertanian, 14(1), Hal 65-72.

Nabil, M. (2005). Pemanfaatan Limbah Tulang Ikan Tuna (Thunnus sp.) sebagai Sumber Kalsium dengan Metode Hidrolisis Protein. Skripsi. Fakultas Perikanan dan Ilmu Kelautan IPB. Bogor.

Noviyarsi, dkk. 2015. Potensi Briket Arang Berbahan Sekam Sebagai Energi Alternatif. Seminar Nasional Teknologi Informasi, Komunikasi dan Industri. ISSN 2085-9902.

Palupi, R. (2007). Pengaruh Pengolahan Limbah Udang Terhadap Nilai Gizi Dan Daya Cerna Proteinnya. Fakultas Pertanian Universitas Sriwijaya. Palembang.

Pane, J.P., Junary, E., \& Herlina, N. (2015). Pengaruh Konsentrasi Perekat Tepung Tapioka dan Penambahan Kapur dalam Pembuatan Briket Arang Berbahan Baku Pelepah Aren (Arenga Pinnata). Jurnal Teknik Kimia, 4(2), Hal 32-38.

Putra, H.P, dkk. (2013). Studi Kualitas Briket dari Tandan Kosong Kelapa Sawit dengan Perekat Limbah Nasi. Jurnal Sains dan Teknologi Lingkungan, 5(1). Hal 27-35. 
Putra, H.P., Modokompit, M., \& Kuntari, A.P. (2013). Study Karakteristik Briket Berbahan Dasar Limbah Bambu dengan Mneggunakan Perekat Nasi. Jurnal Teknologi, 6(2), Hal 116-123.

Putro, S, dkk. (2015). Variasi Temperatur dan Waktu Karbonisasi untuk Meningkatkan Nilai Kalor dan Memperbaiki Sifat Proximate Biomassa Sebagai Bahan Pembuat Briket yang Berkualitas. Prosiding Simposium Nasional RAPI XIV. ISSN 1412-9612.

Rasyaf, M. (1992). Pengelolaan Peternakan Unggas Pedaging. Kanisius. Yogyakarta.

Ristiyaningsih, Y., Ulfa, A., \& Syawitri, K.S.R. (2015). Pengaruh Suhu dan Konsentrasi Perekat Terhadap Karakteristik Briket Bioarang Berbahan Baku Tandan Kosong Kelapa Sawit dengan Proses Pirolisis. Jurnal Konversi, 4(2), Hal: 16-22.

Saleh. A, dkk. 2009. Pengaruh Konsentrasi Pelarut, Temperatur dan Waktu Pemaskan pada Pembuatan Pulp dari Sabut Kelapa Muda. Jurnal Teknik Kimia, 16(3), Hal 35-44.

Suryani, I., Permana, U.M.Y., \& Dahlan, M.H. (2012). Pembuatan Briket Arang dari Campuran Buah Bintaro dan Tempurung Kelapa Menggunakan Perekat Amilum. Jurnal Teknik Kimia, 18(1), Hal : 24-29.

Swastawati, F., Ima W., dan Eko S. (2008). Pemanfaatan Limbah Kulit Udang Menjadi Edible Coating Untuk Mengurangi Pencemaran Lingkungan. Jurusan Perikanan Universitas Diponegoro, 4(4).

Winarno, F. G. (1997). Kimia Pangan dan Gizi. PT. Gramedia Pustaka Utama. Jakarta.

Yerizam, M, dkk. (2013). Characteristic of Composite Rice Straw and Coconut Shell asn Biomass Energy Resources (Briquette)(Case Study: Muara Telang Village, Banyuasin of South Sumatra). International Journal on Advanced Science Engineering Information Technology, 3(3), Hal 42-48. 